\title{
THE COVERAGE OF GRAIN CROPS PRODUCTION WITH STORAGE CAPACITIES IN SERBIA
}

\section{POKRIVENOST PROIZVODNJE ZRNASTIH PROIZVODA SKLADIŠNIM KAPACITETIMA U SRBIJI}

\author{
Nebojša NOVKOVIĆ*, Tihomir NOVAKOVIĆ ${ }^{*}$ Beba MUTAVDŽIĆ \\ Nataša VUKELIĆ*, Miljojko JANOŠEVIĆ ${ }^{* *}$ \\ ${ }^{*}$ University of Novi Sad, Faculty of Agriculture, Trg Dositeja Obradovića 8, 21000 Novi Sad, Serbia \\ ${ }^{* *}$ University of Defence, Military Academy, Pavla Jurišića Šturma 1, 11000 Beograd, Serbia \\ e-mail:nesann@polj.uns.ac.rs
}

\begin{abstract}
The subject of this paper is the annual production of important grain crops in Serbia (corn, wheat and soybean), as well as the available grain storage capacities (silos, floor storages and baskets). The aim of this research is to determine the utilization rate of grain crop storage capacities in Serbia as a whole and in four Serbian regions separately according to the average and extreme (maximum) production of the crops examined. On the basis of the analysis conducted, it was noted that the storage capacity in Šumadija, Western Serbia, the Belgrade region and Vojvodina was underutilized, whereas the production in Southern and Eastern Serbia exceeded the available storage capacities. Moreover, considering the data referring to floor storages and silos, it can be concluded that in Southern and Eastern Serbia, the average production exceeded the total available storage capacities by $7.3 \%$, whereas the maximum annual production was $13.7 \%$ higher than the storage capacities.

Key words: grain production, storage capacity, utilization, Serbia.
\end{abstract}

\section{REZIME}

Predmet istraživanja u ovom radu su godišnje proizvodnje značajnih zrnastih proizvoda (kukuruza, pšenice $i$ soje), kao $i$ raspoloživi skladišni kapaciteti (silosi, ambari i koševi) za njihovo skladištenje u Srbiji. Cilj istraživanja je da se utvrdi stepen pokrivenosti skladišnih kapaciteta prosečnom i ekstremnom (maksimalnom) proizvodnjom navedenih useva, za Srbiju u celini i po regionima kojih ima četiri. Kao osnovni izvor podataka za skladišne kapacitete poslužili su zvanični podaci popisa poljoprivrede iz 2012.godine, gde su posmatrani koševi za kukuruz, ambari i silosi. Podaci o godišnjoj proizvodnji kukuruza, pšenice i soje uzeti su iz Statističkih godišnjaka za period 2012-16. Za taj period izračunata je prosečna i maksimalna godišnja proizvodnja. Na osnovu sprovedene analize uočeno je da skladišteni prostor u Šumadiji $i$ Zapadnoj Srbiji, Beogradskom regionu $i$ Vojvodini ostaje neiskorišćen, dok s druge strane u Južnoj i Istočnoj Srbiji proizvodnja prevazilazi raspoloživi skladišteni prostor. Konkretno, koševi za kukuruz su u potpunosti iskorišćeni u Vojvodini, dok u ostalim regionima ostaje neiskoriščeno oko 43\% kapaciteta koševa za kukuruz ukoliko posmatramo prosečnu proizvodnju i 27,1\% u odnosu na maksimalne prinose za posmatrani period. Posmatrajući ambare i silose uočeno je da u Južnoj i Istočnoj Srbiji prosečna proizvodnja prevazilazi za 7,3\% ukupno raspoloživi skladišni kapacitet, dok je maksimalna godišnja proizvodnja veća za $13,7 \%$ od skladištenih kapaciteta. U preostalim regionima ostaje neiskorišćeno 52,1\% ambara i silosa u odnosu na prosečnu proizvodnju i 40,6\% u odnosu na maksimalnu proizvodnju za posmatrani period. Za Srbiju u celini pri prosečnoj proizvodnji, raspoloživi skladišni kapaciteti koševa popunjeni su sa 91,5\%, a silosa i ambara sa $32,7 \%$, dok pri maksimalnoj godišnjoj proizvodnji ta popunjenost iznosi $100 \%$ za koševe za kukuruz, odnosno 53 za silose $i$ ambare.

Ključne reči: proizvodnja zrnastih proizvoda, skladišteni kapaciteti, iskrišćenost, Srbija

\section{INTRODUCTION}

In modern agricultural production, special attention is given to the storage of agricultural products as postponing the product sales can result in a more favorable price and, consequently, greater profit. Storage is especially important for seasonal products such as wheat, corn, soybean, sunflower, etc., which are harvested in certain seasons of the year, but are traded throughout the whole year. Therefore, the present paper is focused on analyzing the production of grain crops (corn, wheat and soybean) and available storage capacities (silos, floor storages and baskets) for these crops in Serbia. The aim of this research is to determine the utilization rate of storage capacities and their territorial distribution across different regions of Serbia. The utilization of storage capacities is analyzed according to the average and maximum annual production of the most significant grain crops (wheat, corn and soybean). The topic of grain and grain crop storage has been analyzed from the organizational-economic perspective in a number of studies:
Bošnjak et al. 1998; Novković 1998; Novković et al. 1990, 2006, 2008, 2015; Novković, Mutavdžic 2007, 2008, 2009.

\section{MATERIAL AND METHOD}

The main source of data on the storage capacities was the official data of 2012 Census of Agriculture, which referred to corn baskets, floor storages and silos. Floor storages refer to the structures usually used for storing grain and other grain products either in bulk or in bags, with natural or mechanical (artificial) ventilation. Corn baskets are structures used for storing corn cob, in which corn is dried by natural or mechanical air circulation. Basket walls are usually made of wire mesh, wooden boards or wicker. Corn is protected from rain and snow by constructing wider eaves. Filling and emptying of the baskets can be manual or mechanical using a corn conveyor. Silos are structures used for storing grains in separate vertical cells, which may be single or grouped in larger numbers. The cells are circular in shape, with a diameter of up to five meters. Silos provide optimum storage conditions, while the processes of transportation, 
cleaning and drying of the products are usually fully mechanized (Statistical Office of the Republic of Serbia, 2012). Conversely, the data on the annual production of corn, wheat and soybeans were obtained from the Statistical Yearbooks for the period 2012-16. On the basis of these data, the average and maximum annual production was calculated for this period. Based on the collected data, the percentage of utilization of the storage capacities (corn baskets, floor storages and silos) was determined according to the average and maximum annual production of grain crops for the period under consideration.

\section{RESULTS AND DISCUSSION}

The total available capacities of corn baskets by regions are given in Table 1 . In order to compare the sizes of the storage capacities, it was necessary to analyze them by units of mass, since the annual production is given in tons, not in the units of volume. The official data are presented as volume in $\mathrm{m} 3$, thus for the purpose of this analysis, it was necessary to express the available capacities of the baskets in tons. It is important to emphasize that the total capacity is divided into the used and owned capacity. Namely, the data on the storage area obtained from the 2012 Census of Agriculture were collected exclusively for farms, i.e. legal entities, entrepreneurs and households, which by definition, in the methodological framework, meet the requirement of being a farm. Such structures for storing agricultural products are marked as owned capacities. On the other hand, the Census did not include the data on the storage structures held by legal entities, entrepreneurs and households which are not engaged in the primary agricultural production, i.e. which by definition do not meet the requirement of being a farm. However, as farms are allowed to use these structures, they are marked as used capacities. The structures are thus presented according to the location of the farm, which means that a farm from one municipality can use storage capacities located on the territory of another municipality (Statistical Office of the Republic of Serbia, 2012).

In previous research, it was determined that $340 \mathrm{~kg}$ of ears of corn can be stored in $1 \mathrm{~m} 3$, so the required capacity expressed in tons was obtained by multiplying the second column by 0.34 .

Table 1. Available capacities of corn baskets in Serbia by regions

\begin{tabular}{||c|c|c||}
\hline Region & Total volume $\left(\mathrm{m}^{3}\right)$ & Mass capacity $(\mathrm{t})$ \\
\hline Belgrade region & $1,294,211$ & 440,032 \\
\hline Vojvodina & $8,979,530$ & $3,053,040$ \\
\hline $\begin{array}{c}\text { Šmadija i western } \\
\text { Serbia }\end{array}$ & $5,467,049$ & $1,858,797$ \\
\hline $\begin{array}{c}\text { Southern and wastern } \\
\text { Serbia }\end{array}$ & $3,662,775$ & $1,245,344$ \\
\hline Total & $19,403,565$ & $6,597,213$ \\
\hline
\end{tabular}

Table 1 shows that as much as $46.3 \%$ of the total capacities of corn baskets are located in the territory of Vojvodina, followed by the region of Šumadija and Western Serbia accounting for $28.2 \%$, the territory of Southern and Eastern Serbia accounting for $18.9 \%$, and finally the territory of the Belgrade region with $6.6 \%$ of the total capacities. The capacities of the floor storages, which are expressed in $\mathrm{m} 3$ in the official data of the Statistical Office, were calculated in a similar manner. For the purpose of the analysis, the total capacities of the floor storages were converted into tons by multiplying the total capacities (the sum of the owned and used capacities) expressed in $\mathrm{m} 3$ by 0.068 . This due to the fact that the utilization of storage area in the floor storages is $20 \%$, thus the value of
0.068 was obtained by multiplying 0.340 by 0.2 . The results obtained are shown in Table 2.

Table 2. Available capacities of floor storages in Serbia by regions

\begin{tabular}{|c|c|c|}
\hline Region & Total volume $\left(\mathrm{m}^{3}\right)$ & Mass capacity $(\mathrm{t})$ \\
\hline Belgrade region & 352,080 & 23,941 \\
\hline Vojvodina & $1,352,536$ & 91,972 \\
\hline $\begin{array}{c}\text { Šumadija i western } \\
\text { Serbia }\end{array}$ & $2,611,395$ & 177,575 \\
\hline $\begin{array}{c}\text { Southern and eastern } \\
\text { Serbia }\end{array}$ & $2,254,529$ & 153,308 \\
\hline Total & $6,570,540$ & 446,796 \\
\hline
\end{tabular}

The data obtained indicate that the largest share of floor storages is located in the region of Šumadija and western Serbia (39.7\%), followed by Southern and Eastern Serbia (34.3\%), Vojvodina (20.6 \%), and the Belgrade region only (5.4\%). The capacities of silos are already expressed in tons, so no conversion was required. The available capacities of silos in the Republic of Serbia by regions expressed in tons are presented in Table 3.

Table 3. Available capacities of silos in Serbia by regions

\begin{tabular}{||c|c|}
\hline Region & Mass capacity $(\mathrm{t})$ \\
\hline Belgrade region & 223,088 \\
\hline Vojvodina & $7,583,442$ \\
\hline Šumadija i western Serbia & 623,464 \\
\hline Southern and eastern Serbia & 320,198 \\
\hline Total & $8,750,192$ \\
\hline
\end{tabular}

Table 3 shows that Vojvodina is absolutely dominant in terms of the available capacities of silos. As much as $86.7 \%$ of the total capacities are located in the territory of Vojvodina. The remaining $13.3 \%$ are distributed across other regions of Serbia in the following order: Šumadija and Western Serbia $7.1 \%$, Southern and Eastern Serbia 3.7 \%, and the Belgrade region 2.5 $\%$. In addition to examining the available structures for storing agricultural products, the analysis also included the annual production of the three most important grain crops for storing (namely wheat, soybean and corn) in the period 2012-16. The aim of the analysis was to compare the available storage capacities with the production of these crops in the period under consideration, thus assessing the utilization rate of storage capacities by individual regions and for Serbia as a whole. The average and maximum annual production was analyzed for the given period. The results of the analysis are shown in Table 4 . The largest share of wheat production is provided by Vojvodina, where, on average, about $60 \%$ of wheat is produced. Vojvodina is also dominant in the production of other crops, so, on average, around $66 \%$ of corn and even $93 \%$ of soybean is produced in this region. The Belgrade region, on average, accounts for $4.7 \%$ of the total wheat production, $3.7 \%$ of the total corn production and $2.6 \%$ of soybean production. The region of Šumadija and Western Serbia, on average, accounts for 16, 17.6 and $4.2 \%$ of the total wheat, corn and soybean production, respectively, whereas Southern and Eastern Serbia provide, on average, 19.9, 13.1 and $0.3 \%$ of the total quantities of the produced wheat, corn and soybean. The data on the extreme productions clearly show that the region of Vojvodina is dominant also in this category, as the studied crops are cultivated most in this territory. The region of Vojvodina is dominant in the production of all studied crops since most of grain crop production takes place in this region. However, the question arises as to whether 
Table 4. Average and maximum annual production of wheat, corn and soybean by regions for the period 2012-16

\begin{tabular}{|c|c|c|c|c|c|c||}
\hline \multirow{2}{*}{ Region } & \multicolumn{2}{|c|}{ Wheat $(\mathrm{t})$} & \multicolumn{2}{c|}{ Corn (t) } & \multicolumn{2}{c|}{ Soybean $(\mathrm{t})$} \\
\cline { 2 - 7 } & Average & Max & Average & Max & Average & Max \\
\hline Belgrade region & 120,163 & 126,981 & 220,963 & 292,132 & 11,446 & 14,875 \\
\hline Vojvodina & $1,522,422$ & $1,775,668$ & $3,960,720$ & $5,361,294$ & 416,718 & 534,673 \\
\hline $\begin{array}{c}\text { Sumadija and } \\
\text { western Serbia }\end{array}$ & 408,574 & 460,463 & $1,065,303$ & $1,348,178$ & 19,029 & 25,532 \\
\hline $\begin{array}{c}\text { Southern and } \\
\text { eastern Serbia }\end{array}$ & 506,728 & 536,265 & 789,049 & 993,386 & 1,333 & 2,019 \\
\hline Total & $2,557,887$ & $2,899,377$ & $6,036,035$ & $7,994,990$ & 448,526 & 577,099 \\
\hline
\end{tabular}

Table 5. Utilization rate of storage capacities in relation to the average production values by regions for the period 2012-16

\begin{tabular}{|c|c|c|c|c|c|c|c||}
\hline \multirow{2}{*}{ Region } & \multicolumn{3}{|c|}{ Production (t) } & \multicolumn{2}{c|}{ Capacities $(\mathrm{t})$} & \multicolumn{2}{c|}{$\%$} \\
\cline { 2 - 8 } & Wheat & Corn & Soybean & Baskets & $\begin{array}{c}\text { Floor } \\
\text { storages+ } \\
\text { silos }\end{array}$ & Baskets & $\begin{array}{c}\text { Floor } \\
\text { storages } \\
\text { silos }\end{array}$ \\
\hline $\begin{array}{c}\text { Belgrade } \\
\text { region }\end{array}$ & 120,163 & 220,963 & 11,446 & 440,032 & 247,029 & 50.2 & 53.3 \\
\hline $\begin{array}{c}\text { Vojvodina } \\
\text { Somadija } \\
\text { and western } \\
\text { Serbia }\end{array}$ & $1,522,422$ & $3,960,720$ & 416,718 & $3,053,040$ & $7,675,414$ & 100 & 37.1 \\
\hline $\begin{array}{c}\text { Southern } \\
\text { and eastern } \\
\text { Serbia }\end{array}$ & 506,729 & 789,049 & 1,333 & $1,245,343$ & 473,506 & 63.4 & $107.3^{*}$ \\
\hline Total & $2,557,888$ & $6,036,035$ & 448,526 & $6,597,212$ & $9,196,988$ & 91.5 & 32.7 \\
\hline \hline
\end{tabular}

the distribution of the existing storage capacities is in accordance with the previously analyzed distribution of production outputs by regions. In order to provide the answer to this question, it is necessary to compare the storage capacities by regions with the production outputs for the studied period. Table 5 presents the utilization rate of storage capacities in relation to the average production values by regions for the studied period 2012-16.

The utilization rate of the corn baskets depends exclusively on the production of corn. The capacities of the floor storages and silos, on the other hand, were examined collectively starting from the assumption that, unlike the baskets, they can be used also for storing other grain crops. The capacities of the corn baskets in all regions (except in Vojvodina) meet the corn storage requirements as the capacities exceed the average level of the total corn production. The percentage of utilization of the corn baskets in the Belgrade region, Šmadija and Western Serbia, and South and Eastern Serbia is 50.2, 57.3 and $63.4 \%$, respectively. Only in Vojvodina is the average corn production for the studied period 2012-16 higher than the storage capacities of baskets, so that the remaining corn needs to be stored in floor storages and silos.

Floor storages and silos can be used for storing other grain crops studied in this research. When determining the utilization rate of floor storages and silos, the average annual production of soybean and wheat is combined (in Vojvodina also together with the remaining corn which cannot be stored in baskets). In three out of the four regions, the floor storages and silos are mostly underutilized, so in the Belgrade region the utilization of floor storages and silos is 53.3 $\%$, in Vojvodina it is only $37.1 \%$, and in Šumadija and Western Serbia it is $53.4 \%$. Interestingly, in Southern and Eastern Serbia, the average soybean and wheat production exceeds the storage capacities of the floor storages and silos by $7.3 \%$. This difference between the storage capacities of the floor storages and silos and the average production in this region is in practice even higher considering that many producers store corn directly in silos.

Similar analysis was carried out also for the maximum production, so the production peaks were compared with the storage capacities. The aim of this analysis was to determine the utilization of the storage capacities in the years when agricultural production is extremely high. Therefore, it is possible to address the issue of whether the storage capacities are sufficient for higher levels of production in the future. Table 6 shows the utilization rate of the storage capacities in relation to the maximum annual production of the studied grain crops for the period 2012-16.

Relative to the extreme production, corn baskets are also largely underutilized, except in Vojvodina, where corn production exceeds the storage capacities of the corn baskets available not only in the periods of the highest production, but also with the average level of production. The utilization rate of the baskets in Belgrade region is $66.39 \%$, in Šumadija and Western Serbia it is $72.53 \%$ and in Southern and Eastern Serbia it is $79.77 \%$.

Based on the data on the floor storages and silos, it can be concluded that the storage capacities are generally sufficient even for extreme yields. This conclusion I s drawn from the fact that even with extreme yields the capacities of floor storages and silos are underutilized. The utilization rates in the Belgrade region, Vojvodina and Šumadija and Western Serbia are 57.42 $\%, 60.17 \%$ and $60.67 \%$, respectively. Nevertheless, the storage capacities in Southern and Eastern Serbia are insufficient to hold the maximum yields of soybean and wheat. Therefore, the maximum values of soybean and wheat production exceed the capacities of the floor storages and silos available by $13.68 \%$ of the total storage capacities.

Provided the storage capacities are analyzed for the whole Serbia relative to the average yields, both the corn baskets and

Table 6 Utilization rate of the storage capacities in relation to the maximum production by regions for the period 2012-16

\begin{tabular}{|c|c|c|c|c|c|c|c||}
\hline \multirow{2}{*}{ Region } & \multicolumn{3}{|c|}{ Production (t) } & \multicolumn{2}{c|}{ Capacities $(\mathrm{t})$} & \multicolumn{2}{c||}{$\%$} \\
\cline { 2 - 9 } & Wheat & Corn & Soybean & Baskets & $\begin{array}{c}\text { Floor } \\
\text { storages+ } \\
\text { silos }\end{array}$ & $\begin{array}{c}\text { Floor } \\
\text { Baskets }\end{array}$ & $\begin{array}{c}\text { storages+ } \\
\text { silos }\end{array}$ \\
\hline $\begin{array}{c}\text { Belgrade } \\
\text { region }\end{array}$ & 126,981 & 292,132 & 14,875 & 440,032 & 247,029 & 66.4 & 57.4 \\
\hline Vojvodina & $1,775,668$ & $5,361,294$ & 534,673 & $3,053,040$ & $7,675,414$ & 100 & 60.2 \\
\hline $\begin{array}{c}\text { Sumadija and } \\
\text { western } \\
\text { Serbia }\end{array}$ & 460,463 & $1,348,178$ & 25,532 & $1,858,797$ & 801,039 & 72.5 & 60.7 \\
\hline $\begin{array}{c}\text { Southern and } \\
\text { eastern Serbia }\end{array}$ & 536,265 & 993,386 & 2,019 & $1,245,344$ & 473,506 & 79.8 & $113.7^{*}$ \\
\hline Total & $2,899,377$ & $7,994,990$ & 577,099 & $6,597,213$ & $9,196,988$ & 100.00 & 53.00 \\
\hline \hline
\end{tabular}


the cumulative capacities of the floor storages and silos are underutilized. Conversely, by analyzing the maximum annual production, the corn baskets are insufficient to store the entire corn yield. There is still free space in floor storages and silos, which are only $53 \%$ utilized even in the case of the maximum yields. However, it should be noted that these storage capacities are used also for storing other, less cultivated grain crops (sunflower, barley, rye ...).

\section{CONCLUSION}

On the basis of the conducted research, it was determined that the corn baskets are fully utilized only in Vojvodina, whereas this is not the case in other parts of Serbia. In other regions, around $43 \%$ of the corn baskets are unutilized relative to the average crops production, whereas as much as $27.1 \%$ is unutilized in relation to the maximum yields in the studied period. At level of the whole Serbia, the corn baskets were fully utilized only relative to the maximum production, whereas a total of $91.5 \%$ is used in relation to the average production. In the region of Southern and Eastern Serbia, there is a real need for constructing new silos and floor storages that would enable storing of the entire yield of wheat and soybean from the region. The need for constructing new storage capacities is even greater since the production of grain crops, especially soybean, is expected to increase. In Southern and Eastern Serbia, the average production exceeds the total available storage capacities by $7.3 \%$, whereas the maximum annual production is $13.7 \%$ higher than the storage capacities. Nevertheless, in other regions, $52.1 \%$ of the floor storages and silos are unutilized with regard to the average crops production, and $40.6 \%$ of these storage capacities are unutilized relative to the maximum production for the studied period. At the level of the whole Serbia, a total of $32.7 \%$ of the available storage capacities of floor storages and silos are used, whereas $53 \%$ of these capacities are utilized relative to the maximum annual production. On balance, it can be concluded that, at the level of the whole Serbia, the floor storages and silos are still underutilized and their territorial distribution is not optimal.

\section{REFERENCES}

Bošnjak, Danica, Tica, N., Jovanović, M., Novković, N., Obrenović, D. (1994). Organizaciono-ekonomska obeležja strnih žita, XV poglavlje u monografiji Mehanizovana proizvodnja strnih žita, Poljoprivredni fakultet, Novi Sad, 103108.

Novković, N., Potkonjak, Svetlana, Jovanović, M., Bošnjak, Danica, Lučić, Đ. (1990). Moguće varijante investicija poglavlje 5 u studiji Mogućnosti investiranja u proizvodnju hrane Vojvodine, Elaborat, recenziran, Sekretarijat za poljoprivredu, PIV, Novi Sad, 66-100.

Novković, N. (1998). Menadžment poljoprivredne proizvodnje, Journal on Processing and Energy in Agriculture (former PTEP), 1-2, 13-15.

Novković, N. Ceranić, S. Ranković, R. (2001). Metode menadžmenta logistike hrane, Strategijski menadžment br.4/2001, 83-88.

Novković, N., Ćosović, J., Šilić Jasna, Topić, M. (2006). Efekti investiranja u proširenje kapaciteta silosa - Studija slučaja, Journal on Processing and Energy in Agriculture (former PTEP), 1-2, 50-53.

Novković, N., Mutavdžić Beba (2007). Uticaj sezonskih kolebanja cena žitarica na ekonomsku efektivnost silosa, Journal on Processing and Energy in Agriculture (former PTEP), 1-2, 49-51.

Novković, N., Mutavdžić Beba (2008). Ekonomska isplativost izgradnje rečne luke i skladišta za žito, Journal on Processing and Energy in Agriculture (former PTEP), 3, 151-154.

Matković, M., Novković, N., Janošević, M. (2008). Značaj informacionih osnova za izradu i ocenu investicionih planova na poljoprivrednim gazdinstvima, Agroekonomika br.39-40, 53-60.

Novković, N., Mutavdžić Beba (2009). Ekonomski efekti skladištenja žitarica, Journal on Processing and Energy in Agriculture (former PTEP), 13(1), 54-57.

Novkovic, N., Stojaković Dragana, Janošević, M. (2015). Ocena specifičnih investicija u poljoprivredi, Agroekonomika 65, Univerzitet u Novom Sadu, Poljoprivredni fakultet, Departman za ekonomiku poljoprivrede i sociologiju sela ISSN 03505928. 1-9.

Popis poljoprivrede (2012), Republički savez za statistiku metodološka objašnjenja, Beograd, Srbija

Received: 07. 03. 2018.

Accepted: 30. 03. 2018. 